\title{
TRANSLATION OF CHILDREN'S STORYBOOK FROM THE SKOPOS THEORY PERSPECTIVE
}

\author{
Siti Luruh Ayu Noerjanah \\ Iain Syekh Nurjati Cirebon \\ Luruh4yu@Gmail.Com
}

\begin{abstract}
This study investigated the strategies applied by the translator in translating a series of bilingual children storybook (Indonesia-English) entitled: Kancil Jadi Raja (Mouse Deer Becomes King) published by Dinar Media, Jakarta and the appropriateness of the translation result with Skopos theory. This study employed a descriptive qualitative study design. Total sampling was applied to collect the data. The data were collected from the texts of the bilingual children's storybook or document analysis. The researcher analysed the documents using the microstructural analysis introduced by Leuven Zwart (1989-1990), an expert in translation studies which developed a comparative model of texts analysis, where the source texts and target texts was compared to identify the translation strategies, The texts consist of 59 sentences. The data shows that: 1.) There were eleven (11) types of translation strategies applied by the translator which was in line with skopos theory or more likely to emphasized on the Target Text (TT), among others: Transference strategy applied six (6) times , Cultural Equivalent strategy applied sthirty two (32) times, Transposition strategy applied nine (9) times, Modulation strategy applied seven (7) times, Reduction strategy applied eight (8) times, Expansion strategy applied six (6) times, Couplets strategy applied twelve (12) times, Triplets strategy applied eight (8) times, Quadruplets strategy applied four (4) times, Notes strategy applied two (2) times and Synonymy strategy applied two (2) times. This study concludes that the translation result was appropriate with skopos theory.
\end{abstract}

Keywords: Translation, Skopos, translation strategies, Bilingual children's storybook. 


\section{BACKGROUND}

Translation is one of the major branches in applied linguistics studies, which become one of the important skills in language studies. Translating involved a text from source language (SL) to be translated into the target text (TT) which include delivering acceptable and appropriate message. Translation are applicable for both literary and non-literary (factual) texts. The literary text consist of plays, novels, fabels, song lyrics, mimes, movie scripts, fairy tales and soap operas (Anderson and Anderson: 1997).

Children's story book has significant role in language learning, most are in the form of fables and fairy tales, especially the bilingual storybook which enable children to learn their first language (L1) as well as the foreign language. The most common form of bilingual children's story book in Indonesia is English - Indonesia or Indonesia - English version. Bilingual books it self are books with two different languages written either on the same page or facing pages. Here, children are introduced with other language as well as other culture that coexist in the bilingual books. This also means that they are introduced with words that probably are new and unfamiliar to them in order to develop their vocabularies.

In bilingual children's story books, translation plays a crucial role in delivering the message of source language (SL) to the target language (TL) naturally, accurately and readable (Newmark: 1988). The person who is incharge of translating a text is certainly the translator, where he or she should bear in mind that the diction must be chosen wisely since the reader of these texts are children and their parents. Hadaway and Young (2013) cited in Semingson, Pole and Tommerdahl (2015) are on the same page regarding the idioms, humor, culture, and syntax expressed across languages requires special attention so that the intent of the story is communicated as naturally and accurately as possible.

Translating a children storybook is challenging. However, a translator are given the privilege to translate a text applying certain methods, procedures or strategies and and it is expected that one or more theories of translation will be consistent with the translation result. One the theories in translation studies is Skopos. This theory explains that translating a text is considered as human action and every translation has a purpose or aim or goal and this theory emphasized on texts which are translated based on the request of commisioner whether it is for commercial or non commercial purpose. Therefore, the bilingual children's storybook is considered adequate to be analysed from the Skopos theory paradigm.

In this study the researcher analyses the strategies applied by the translator in translating the children's storybook and the appropriateness of the translation product with Skopos theory. The researcher agrees with this theory since human being produces something with purrpose, aim or goal, it is what a translation is or a translator for which is to produce an adequate and appropriate translation product to be comprehend by the reader.

Translation are described in many perspective or theories, it depends on the scholars or experts. Newmark (1988) as well as Hatim and Munday (2004) agree that translation is the replacement or the transfer of written message/language/text of one language to the other. Bell (1991) is similar to Nida and Taber (1982) which described translation as replacing or to producing a text with another text of foreign language which is equivalent in terms of semantic or meaning and style. Theodore Savory (1968: 13) on the other hand, provides a slightly different definition which is similar to Larson's definition where both scholars emphasize on the translation's meaning. Savory 
defines that translation is possible if there are two equivalent ideas that lies behind different verbal expressions. Larson (1984: 3), identifies that translation consists of studying the lexicon, grammatical structure, communication situation and cultural context language text, analyzing of the source in order to determine its meaning, and then reconstructing this same meaning using the lexicon and grammatical structure which appropriate in the receptor language and its cultural context. Larson's theory explains that meaning is a very significant aspect in translation.

In the Functional approach paradigm, a translation is described as producing a functionally appropriate target text (TT) based on the source text (ST) and the connection between both texts is based on the purpose of translating or skopos (Schäffner cited in Baker and Malmkjaer, 2001: 237). In other words, translation is offering information to members of one culture in their language (the target language and the culture) about information originally offered in another language within another culture (the source language and culture) or in other explanation, this could refer to an interaction between SL and TL intentionally (Reiss and Vermeer, 1984/1981 in Baker and Malmkjaer 2001: 236; Nord, 1997).

Skopos is taken from a Greek word which has the meaning of purpose, aim or goal. Both Katharina Reiss and Hans. J. Vermeer in the late 1970s have developed this theory. It is under the umbrella of Functional approach paradigm. According to Reiss (cited in Nord: 1997), the ideal translation would be one "in which the aim in the TL [target language] is equivalenc e as regards the conceptual content, linguistic form and communicative function of a SL [source-language] text." Vermeer (cited in Nord, 1997) defines translation as human action which is intentional, purposeful behaviour that takes place in a given situation; it is part of the situation at the same time as it modifies the situation. Another scholar who is also developing the functional approach paradigm define translation as producing a functionally appropriate target text based on the source text and the connection between both texts is based on the purpose of translating or skopos (Schäffner cited in Baker and Malmkjaer, 2001: 237). In other words, translation is offering information to members of one culture in their language (the target language and the culture) about information originally offered in another language within another culture (the source language and culture) or in other explanation, this could refer to an interaction between SL and TL intentionally (Reiss and Vermeer, 1984/1981 in Baker and Malmkjaer 2001: 236; Nord, 1997, 2007:1).

Christiane Nord (1988) and Holz-Mänttäri (1984) also develop a related theory which reflects a general shift from predominantly linguistic and rather formal translation theories to a more functionally and socioculturally oriented concept of translation (Schäffner in Baker and Malmkjaer, 2001:235). Translation action according to Skopos is focused on producing a TT that is appropriate for the receiver. This means that the TT must be suitable with the TT culture.

Before a translator translates a text, he/she must first define the Skopos or purpose or aim or goal. Here, Translation is viewed as a human action or certain behavior. An action always has a purpose and translation action has an outcome, it is the translatum as a particular variety of target text (Vermeer, 1986 in Venuti, 2000: 227).

Skopos theory has important factors, which are the same with the factors in Action theory. The factors are the culture of the intended readers of the target text and the client who has commissioned it, in particular, the function which the text is to perform in that culture for those readers (Baker and Malmkjaer, 2001: 235). In Skopos theory paradigm, commission is an instruction given by a certain people or by ourselves 
to carry out the instruction that has been given. A commission is another term for translation brief or translation's job description. A commission formulated as detailed information as possible on (1) the goal, a specification of the aim of the commission. (2) the condition under which the intended goal should be attained. The statement of the goal and the conditions should be explicitly negotiated between the client (commissioner) and the translator (Vermeer cited in Venuti, 2000: 235). The commission has an important role; the translator needs to compare ST and TT profiles define in the commission to see where the differences of the two texts.

The translation commission should give the following information for both texts. The descriptions are as follows (Nord, 1997):

- The intended text functions

- The addressees.

- The time and place of text reception

- The Medium

- The Motive (purpose of publishing and translating the book).

In accordance with the commission, a translator has the obligation or the responsibility to fulfill the goal of translation not only to texts but more importantly to people: senders, clients, and receivers and all of whom merit the translator's loyalty as he/she is the expert or a professional in translation (Vermeer (1989) in Pym, 2010: 55; Nord (1997) in Pym (2010: 55); Robinson, (1997: 29); Holz Mänttäri (1984) in Venuti (2000: 235). The concept of loyalty is invoked in order to deal with Skopos problems of the translation purpose as specified by the brief/commission is at variance with the original author's intention; The commissioning brief is incompatible with culturallysanctioned translation practices. (Hatim, 2001: 79):

Other important parts of Skopos theory are the text type and language function. Reiss (2000: 26) classifies the bilingual children's story book as the Form-focused (Expressive) text types, where children's storybook is a literary text and Appealed-focus (Operative) text types, where children storybook has the ability to make a children act or imagine as if he or she is one of the character in the story.

In developing this theory, Skopos has rules or principles for translator to follow. These rules are proposes by Hans. J. Vermeer. The skopos rules definition is as follows:

translate/interpret/speak/write in a way that enables your text/translation to function in the situation in which it is used and with the people who want to use it and precisely in the way they want to function (Vermeer, 1989 in Pym, 2010: 45).

Reiss and Vermeer (1984 cited in Munday, 2001: 79) describe the basic rules of skopos theory as follows:

1. A translatum (or TT) is determined by its skopos.

2. A TT is an offer of information (informationsangebot) in a target culture and TL concerning an offer of information in a source culture and SL.

3. A TT does not initiate an offer of information in a clearly reversible way.

4. A TT must be internally coherent.

5. A TT must be coherent with ST.

6. The five rules above stand in hierarchical order, with the skopos rule predominating. 
The advantage of skopos theory is that it gives translators the possibility to translate the same text in different ways according to the purpose or aim or goal of the TT and the commission (Munday, 2001: 80).

Strategies of translation involve the basic tasks of choosing the foreign text to be translated and developing a method to translate it (Venuti in Baker and Malmkjaer, 2001: 240). Newmark applied procedures to a sentence and the smaller unit of language. Baker (1992: 26) states that translation strategy is a procedure for solving a problem encountered in translating a text or a segment of it. Different experts have different terms concerning translation strategies. Strategies (Baker, Schaffner, Munday, House, Venuti) also referred to 'techniques' (Molina and Albir),' procedures' (Newmark, Bastin), or 'methods' (Vinay and Darbelnet). This research applies the term strategy, because it is considered more natural and general. As for the strategies, Schleiermacher introduces the Domestication (the reduction of the foreign text to the socio-cultural of target-language, bringing the author back home; emphasized on the TT) and Foreignizing strategies (it emphasized on socio-cultural values to register the linguistic and cultural difference of the foreign text, sending the reader abroad; emphasized on the ST) as translation strategies (Venuti in Baker and Malmkjaer, 2001: 242). Venuti, similar with Schleiermacher also proposes two wide categories, Domesticating and Foreignizing strategy. Another expert Rainer Schulte and John Bigueret (1992) in Jindan (2011: 31), describe that Domestication refers to the translation method that is focused on the target-language and Foreignization refers to the translation which is focused on the source-language. The originality of the text is preserved. This is permitted in order to give advantage of the new words or phrases from the different language to be familiar to the receivers (Rainer Schulte and John Bigueret, 1992 in Jindan, 2011: 31).

Here are the translation's strategies:

1. Literal Translation (Vinay and Darbelnet, 2000 in Munday, 2001: 56-57; Newmark, 1988: 68; Molina and Albir, 2002:510; Gallagher, 1996: 28; Chesterman, 1997 or Faithful translation (Steiner, 1998) It is a one word to one word translation, through group to group, collocation to collocation clause to clause, clause to clause to sentence to sentence.

2. Transference (loan word, transcription) this term is used by Newmark (1988: 81), while Vinay and Darbelnet (2000) in Munday (2001: 56); Molina and Albir (2002: 510) and Gallagher (1996: 28) proposed the term 'Borrowing' (emprunt). This procedure emphasized on the transfer of an SL word to TL. Since there are no equivalent word in TT. For example: names of living and most dead people; geographical and topographical names such as Bandung city, Jakarta, etc including newly independent countries such as Timor Leste, etc. Names of periodicals and newspapers; titles of as yet untranslated literary works, plays, films; names of private companies and institutions; names of public or nationalized institutions, unless they have recognised translations.

3. Naturalisation proposes by Newmark (1988: 82), while Molina and Albir 2002: 510) used the term' Generalization'. This procedure resemblance transference and adapts the SL word first to the normal pronunciation, then to the normal morphology (word-form) of the TL. For example: the word composition in ST become 'komposisi' in TT. 
4. Cultural Equivalent proposes by Newmark (1988: 82), while Vinay and Darbelnet (2000) in Munday (2001: 58) uses the term 'Equivalent' and Molina and Albir (2002: 509); Gallagher (1996: 28) introduce the term 'Adaptation'. This is an exact translation where a SL cultural word is translated by a TL cultural word. For example: the word sepakbola in ST become soccer in TT.

5. Functional Equivalent introduces by Newmark (1988: 83) while Molina and Albir (2002: 510) introduce the term 'Particularization'. This procedure, applied to cultural words, requires the use of a culture-free word, sometimes with a new specific term; it therefore neutralises or generalises the SL word. For example: the word pesawat terbang in ST become 'air transportation' in TT.

6. Descriptive Equivalent introduces by Newmark (1988: 83) Molina and Albir (2002: 510) introduce the term 'Description', Vinay and Darbelnet (2000) in Munday (2001:58) used the term Equivalent. Here, description and function is an important element in explanation and also in translation. For example, 'Keris' described as 'the javanese aristrocacy weapon and sometimes it refer to a mystical thing.

7. Synonymy. Introduce by Newmark (1988: 84), while Molina and Albir (2002: 510) introduce the term 'Discursive Creation'. This procedure is used where there is no clear one-to-one equivalent and the word is not important in the text, in particular for adjectives or adverbs of quality. For example: the phrase rendah hati in ST become 'humble' in TT, the word canggung in ST become 'awkward' in TT.

8. Through-Translation introduce by Newmark, (1988: 84). This stategy is also called 'Calque', which introduces by Vinay and Darbelnet (2000) in Munday (2001: 56), and Molina and Albir (2002: 510). It is the literal translation of common collocations, names of organization, the component of compound and perhaps phrase is known as through translation. For example: the names of international organisations which often consist of 'universal' words. For example: Kemendiknas became The Ministry of National Education and the phrase tingkat suku bunga in ST became 'Interest' in TT.

9. Transposition proposed by Vinay and Darbelnet (2000) in Munday (2001: 57); Newmark (1988: 85); Gallagher (1996: 28) and Molina and Albir (2002: 511), while Catford in Munday (2001:60) and Van Leuven-Zwart (1989) in Munday (2001:63) named this strategy as 'Shifts'. This procedure is changing the grammar from SL to TL. Transposition consists of (1) the change from singular to plural, (2) a grammatical structure of SL does not exist in TL (gerund can be translated by verb-noun or subordinate clause or a noun infinitive or an infinitine, (3) where literal translation is grammatically possible but may not accord with the natural usage in the TL: SL prepositional phrase, TL preposition; SL adjective noun, TL adverb plus adjective; SL adverbial phrase, TL adverb; SL noun plus adjective, TL noun plus noun; SL verb and present participle, TL verb plus preposition; SL verb, TL verb plus verb- noun; SL noun plus past participle or adjective clause plus noun, TL noun plus preposition plus noun; SL participial clause, TL adverbial clause or group, (4) SL complex sentence converted to TL simple sentences; SL direct speech to TL indirect speech; SL verb to TL noun. For example: singular word buku in ST become 'books' in TT.

10. Modulation proposes by Newmark, 1988: 88; Vinay and Darbelnet, 2000 in Munday, 2001: 57; Gallagher, 1996: 28; Molina and Albir, 2002: 510. It is a 
concrete translation procedure which can be applied in principle to any action (verb) or quality (adjective or adverb): (a) abstract for concrete, (b) cause for effect (c) one part to another (d) reversal of terms (e) active for passive (f) space for time $(\mathrm{g})$ intervals and limits $(\mathrm{h})$ change of symbols. For example: the word ini in ST become 'that' in TT.

11. Recognised Translation introduces by Newmark (1988: 89), while Molina and Albir (2002: 510) uses the term 'Established Equivalent'. Translators should normally use the official or the generally accepted translation of any institutional term. If appropriate you may indirectly show your disagreement with this official version. For example: the word kesalahan in ST become 'error or mistake' in TT.

12. Translation Label introduces by Newmark (1988: 90). This is a conditional translation; usually it has to do with a new institutional term, which should be made in inverted commas, which can later be discreetly withdrawn.

13. Compensation propose by Newmark, 1988: 90; Molina and Albir, 2002: 210; Mailhac, $2007 \quad$ in http://www.pfri.uniri.hr/ bopri/documents/ translationstrategies_002.pdf). This is said to occur when loss of meaning, soundeffect, metaphor or pragmatic effect in one part of a sentence is compensated in another part, or in a contiguous sentence.

14. Componential Analysis propose by Newmark, 1988: 90; Bell, 1991: 87; Larson, 1984: 80. This is the splitting up of a lexical unit into its sense components, often one-to-two, three or four translations.

15. Reduction and Expansion. These procedures of translation is reduced or deleted or omitted a certain word or phrase or even the whole target text; it also expanded or added a word, phrase in TT. For this strategy Molina and Albir (2002: 510) used the same term 'Reduction', another terms were also used for instance, Deletion (Baker, 1992: 40; Mailhac, 2007: 25) and Omission (Bastin in Baker and Malmkjaer, 2001:7; Chesterman in http://www.helsinki.fi/ $\sim$ chesterm/TransTheory.html\#Strategies; Nida in Chesterman http://www.helsinki.fi/ chesterm/TransTheory.html\#Strategies; Davies, 2003 in Jaleniauskiene and Čyčelyté, 2009: 33). But for the 'Expansion' the experts used the term 'Amplification' (Molina and Albir, 2002: 510) and 'Addition' (Chesterman in http://www.helsinki.fi/ chesterm/ TransTheory.html\#Strategies; Nida in Chesterman http://www.helsinki.fi/ chesterm/TransTheory. html\#Strategies; Davies, 2003 in Jaleniauskiene and Čyčelyté, 2009:33 ; Galagher, 1996: 28).

16. Paraphrase (Dryden, 1680 in Baker and Malmkjaer, 2001: 166; Newmark, 1988:90 ; Robinson in Baker and Malmkjaer, 2001: 166) or Free Translation (Catford in Baker and Malmkjaer, 2001: 89; Jerome in Baker and Malmkjaer, 2001: 87). This is an explanation of the meaning of a segment of the text. It is used in a poorly written text or has important implications and omissions.

17. Couplets. Couplets, triplets, quadruplets (Newmark, 1988:91) combine two, three or four of the other procedures for dealing with a single problem. Mailhac (2007:25) uses the term Combination of Procedures.

18. Notes, Addition and Glosses strategy. Notes is providing additional information in a translation. Other expert use the term Amplification' (Molina and Albir, 2002: 510). Additional information in the translation may take various forms: within the text, at the bottom of the page, at the end of a chapter, or at the end of a book. 
In translating a text, the translator's own role, purposes and socio-cultural aspects effect the selection of the translation strategy or in other words, the translator has the right to select which translation strategy is most suitable (Munday, 2001: 76; Nord, 1991 in Jindan 2011:8). In line with the Skopos theory, the translation strategies above must be categorised based on the Target text oriented or functionally and socioculturally oriented or the non-literal strategies (Domestication). The translation strategies mentioned below are in accordance with the skopos theory: Transference, Functional Equivalent, Descriptive Equivalent, Cultural Equivalent, Through Translation, Recognised Translation, Reduction and Expansion, Transposition, Modulation, Paraphrase, Couplets, Triplets, Quadruplets and Notes.

\section{Unit of Translation.}

Newmark (1988:65) describes the unit of translation in hierarchical ranking: Text, paragraph, sentence, clause, collocation, word group, word, and morpheme. Roger.T. Bell (1991:29) defines the units of translation as: the smallest segment of an SL (source language) text which can be translated, as a whole, in isolation from other segments. It normally ranges from the word through the collocation to the clause. It could be described as 'as small as is possible and as large as is necessary' (this is my view), though some translators would say that it is misleading concept, since the only UT is the whole text.

Nord (1993: 16) describes the unit of translation in a vertical way, this means that the text is seen as a hyper-unit comprising functional units that are not rank-bound, that can occur at any level anywhere in the text, among others: the text, paragraphs, sentence stuctures and grammar, words and phrase, word formation and sound patterns, intination, focus points. The above definitions of unit of translation have the same point, one of them is the sentence as a unit of translation. Newmark (1988: 31) gives a clearer statement about the sentence as the unit of translation, 'Since the sentence is the basic unit of thought...., so the sentence is, in the first instance, your unit of translation'. Therefore, the translation strategies analysis applying sentence as the unit of translation.

\section{Bilingual children's storybook.}

Narrative text consists of many different types. For example, folktales, fairytales, fables, myths, legends, science fiction, modern fantasy, short stories, picture story books, and ballads (Raison at al, 1994 in Suryana, 2007: 6). Story is a way to attract young learner to learn English. Stories provide a whole imaginary world with the use of language that children can access and enjoy as well as learning the language (Cameron, 2001:159). Moreover, there are other reasons why stories should play a central role in teaching and learning foreign language: Stories which rely so much on words provide a major and constant source of language experience for children. Stories motivate children to learn foreign language, increasing children's ability in listening, reading, speaking and writing. It also help children to be aware of the sound and the 'feel' of the foreign language, the experience of the story provoke a response through speaking and writing, and stories also build communication (Wright, 1995: 4-5).

Translating a literary text is considered difficult for many translators (Yuwono, 2005 in Pujianty, 2006:15). This is because there are certain rules in translating children story book/children literature. Furthermore, studies on children literature, the research on translation is rarely conducted (Lathey, 2006 in Sas, 2010: 5). 
Cameron (2001:166) gives characteristics on how a story is considered a quality story. A good story is a story that listeners or readers enjoy, either the children or parents. Quality stories have characters and a plot that engage children. Stories that have the potential to capture children's interest and motivation to learn, along with space for language growth are considered as a quality stories. Jasmin Hana (2011:35-36) stated that a good story has a meaning that builds character on young learner; the content is suitable with the age level of the children.

A good children storybook always has an educating content and message within the story. This may help children in building good characteristics and his/her state of mind. Children storybook can be easily found in bookstores, from the SL storybooks, translated storybooks and also bilingual storybooks. There are many types of children storybook such as, folktales, fairytales, fables, myths, legends, science fiction, modern fantasy, short stories, picture story books, etc.

Children storybook has different characteristics than the other books (Tiina Puurtinen in Hornby, Pochhacher, and kaindl:1994) stated that these books are very interesting and there are three characteristics that distinguish them from other books, the characteristics are as follows:

a. Children's books are intended for two different groups of readers: first, the children, and second, the adult readers (parents, teachers, critics),

b. Children's literature is ruled by various changing principles and norms, ideological, moral, ethical, religious which determine the types of children's literature provided in a certain time.

c. The special characteristics of child reader is the comprehension and reading ability, the experience of life and knowledge of the world that must be build in their mind in order no to present them with difficult and uninteresting books that may avoid them to reading, but rather to produce books that provoke them to read more.

Wright (1995: 26-37) implies that the existence of pictures, drawing are considered important in creating a fun and wonderful experience and also able to reveal things that words cannot. There is a rule that need to be well understood by a translator in translating children storybook, which is also the main goal; it is the acceptability of the readers. This leads to the adjustment (manipulation of the source text for a certain purpose) conducted by the translator that has a purpose in producing an appropriate translation product for children.

On the other hand, translators also considered that "Translating is a complex activity" (Schaffner and Adab, 2000: viii), "Sulit dan rumit" (Soemarno, 2003 in Nababan, 2008: 9). It would be more problematic when a translator deals with translating children story book. Although it is written by adult, it has its own rules: the use of the language, content, and dictions must be adapted to children's knowledge and fantasy (Yuwono, 2005 in Pujianty, 2006:15). A translator has to apply the appropriate techniques and strategies in translating a children story book in order to have a good result in translation product. Translator's low mastery of techniques is also one of the causes of the unsatisfactory results of translation (Sakri 1985 in Suryana, 2007: 3). Translation involved two different languages and culture. Since a translation is directed to certain reader, a translator needs to consider the option of words, terminology and sentence structure which are suitable for the level of understanding and culture (Ruuskanen, 1996 in Nababan, 2008: 9). Witte in Dollerup and Lindegaard (1994:71) states that a translator has to be "biculturally competent", this means that a translator must have a bilingual competence and understands the knowledge of both culture. 


\section{METHOD}

This study employed descriptive qualitative design. This design was applied in order to obtain detailed information about a phenomenon and describe or discovered what was going on with it without influencing it.

In line with the above theories, the study was concerned with investigating the strategies applied by the translator from the skopos theory perspective and the coherence of the bilingual children's storybook. The total sample is a bilingual children's storybook entitled Kancil Jadi Raja published by Dinar Media, Jakarta. The genre of the storybook was fable and it has 59 sentences.

In qualitative research, the role of the researcher as the primary data collection instrument was crucial. In this research, the instrument was the writer herself as the translation critics.

The research applied the documents analysis procedure which reading every sentences of the bilingual children's storybook (Indonesian-English) and took some notes was an obligation. To analyse what types of strategies applied by the translator, the writer analysed the text based on Micro Structural analysis, because this analysis was at sentence level. This procedure was conducted because all the texts were the data and it was expected to obtain optimum results in the analysis of the translation strategies.

After collecting the data, the next phase was to identify the strategies applied by the translator using the Microstuctural analysis. It compared both the ST (Source Text) and TT (Target Text) in two different parts. Afterwards, from the comparison, the strategies can be identified by the identification of the selection of words from the ST to TT and the sentence's form in from the ST to TT.

As an addition, it would be important to identify whether the bilingual children's storybook were considered as a good translated children's storybook. According to Tiina Puurtinen in Hornby, Pochhacker, Kaindl (1994) in Shadrah (2010: 43), the criteria for a good translation of children's storybook are dynamic style (simple syntactic constructions with finite verbs are preferable), readability and speakability.

\section{FINDINGS AND DISCUSSIONS}

In bilingual children's storybook entitled KANCIL JADI RAJA (Mouse Deer Becomes King) which has been analysed consists of 59 sentences. Here, the researcher found that the translator applied eleven (11) translation strategies, among others: Transference, Cultural Equivalent, Transposition, Modulation, Reduction, Expansion, Couplets, Triplets, Quadruplets, Notes and Synonymy. The analysis is as folow:

1. Transference strategy is applied six (6) times. The example of text analysis:

Source Text (ST): Di suatu pagi yang cerah dihutan tempat kancil dan temantemannya tinggal, matahari baru saja memancarkan cahayanya.

Target Text (TT): One shiny morning in the jungle where kancil (a mouse deer) and his friends lived, the sun's rays had just radiated.

- In this case the mouse deer's name is Kancil. 
2. Cultural Equivalent strategy is applied thirty two (32) times . The example of text analysis:

Source Text (ST): Tiba-tiba mereka dikejutkan oleh suara si Nuri yang bijaksana.

Target Text (TT): Suddenly they were shocked by the wise Parrot's voice.

3. Transposition strategy (A complex sentence converted to two simple sentences) is applied nine (9) times. The example of text analysis:

Source Text (ST): Ada apa gerangan hai burung Nuri, pagi-pagi sudah teriakteriak! Kami semua jadi kaget...", kata si Kerbau.

Target Text (TT): What's the matter hey parrot in early in morning you have kept shouting. All of us are shocked...", said the water buffalo.

4. Modulation strategy (Cause-effect) is applied seven (7) times. The example of text analysis:

Source text (ST): Sang Harimau si Raja hutan yang sudah tua, sekarang sedang sakit keras.

Target Text (TT) : The tiger, the king of the jungle has been old and now he is dying.

5. Reduction strategy is applied eight (8) times. The example of text analysis:

Source Text (ST): Siapa yang dapat menyembuhkan sakit panasnya maka ia akan diangkat menjadi raja hutan pengganti sang harimau.

Target Text (TT): He will be enthroned as the subtitution of the tiger.

(the sentence Siapa yang dapat menyembuhkan sakit panasnya maka and raja hutan in ST is not translated in TT).

6. Expansion strategy is applied six (6) times. The example of text analysis:

Source Text (ST): Oh...alangkah senangnya kalau aku bisa menjadi raja hutan, semua penghuni akan tunduk dan hormat kepadaku”, pikir si monyet dalam hati.

Target Text (TT): Oh...it's beautiful if i can become the king of this jungle. All of inhabitants will obey and respect to me", the monkey thought in his heart. (the word 'this' and 'to' has no equivalent in ST).

7. Couplets strategy is applied twelve (12) times. The example of text analysis:

Source Text (ST): Teman-teman Kancil berfikir sejenak, mereka semua menginginkan dapat merasakan menjadi raja hutan.

Target Text (TT): Kancil's friend thought for a moment, all of them wanted to be the king of the jungle.

In this sentence, the strategies applied by the translator were (1) Transposition (change from plural in ST to singular in TT: the word teman-teman in ST was translated to 'friend' in TT)) and (2) Reduction (the word merasakan in ST is not translated to TT).

8. Triplets strategy is applied eight (8) times. The example of text analysis:

Source Text (ST): Semua penghuni hutan berpencar mencari obat yang namanya air mustika hijau. 
Target Text (TT): All of the jungle inhabitants were dispersed all over to find the medicine, the water of the green magic jewel.

The translator applied: (1) Cultural Equivalent strategy(the phrase penghuni hutan in ST was translated to 'jungle inhabitants' in TT), (2) Expansion (the word berpencar in ST is translated to 'dispersed all over' in TT) and (3) Reduction (the phrase 'namanya' is not translated to TT).

9. Quadruplets strategy is applied four (4) times. The example of text analysis:

Source Text (ST): Begini nyet tadi aku dapat kabar ada yang tahu dimana air mustika hijau itu, tapi syaratnya ia minta beberapa buah kelapa yang ada diatas, gimana kamu mau nggak? Nanti aku kasih tahu, supaya kamunya jadi raja hutan.

Target Text (TT): Well, monkey i have news who knows where the green magic jewel is, but the requisite is he asks some coconut fruit from the above. Do you agree? Then $\mathrm{i}$ give the news. So you can become the king of this jungle".

In this sentence, the strategies applied by the translator were (1) Cultural Equivalent (the phrase begini nyet in ST was translated to 'well, monkey' in TT), (2) Cultural Equivalent (the word syaratnya in ST was translated to 'the requisite' in TT), (3) Cultural Equivalent (the sentence gimana kamu mau nggak? In ST was translated to 'Do you agree?' In TT) and (4) Transposition (a complex sentence converted to three simple sentences).

10. Notes strategy is applied two (2) times. The example of text analysis:

Source Text (ST): Di suatu pagi yang cerah dihutan tempat kancil dan temantemannya tinggal, matahari baru saja memancarkan cahayanya.

Target Text (TT): One shiny morning in the jungle where kancil (a mouse deer) and his friends lived, the sun's rays had just radiated.

*In this case the mouse deer's name is Kancil.

It was the phrase 'a mouse deer' in the TT and notes below the page (footnote: in this case the mouse deer's name is Kancil).

11. Synonymy (There were words, phrase in ST which was translated to other words in TT which had the same meaning with ST) strategy is applied three (3) times. The example of text analysis:

Source Text (ST): Ia tampak memperhatikan teman-temannya.

Target Text (TT): He seemed to pay attention to his friends.

The translation strategies applied by the translator were considered appropriate, since the target text were readable and natural. Moreover, it was the translator's privilege to translate a text in a certain strategies, methods or procedure.

\section{Text Cohesion and Coherence.}

In skopos theory the text should be coherence both ST and TT also on each of the text. however, a coherence text should firstly be cohesive. In order to analyse whether a text is coherent or not, the cohesion must be first analysed. Cohesion is the relation and connections of lexical, grammatical and other components in a text (Baker, 1992: 180; Larson, 1984: 389; Bell, 1991: 165). In order to analyse whether a text is 
cohesive, there are elements that must be identified: reference, subtitution, elipsis, conjunction and lexical cohesion (Baker, 1992: 180). The description is as follows:

\section{Reference}

Reference is generally used to specify the relationship between a word and what it points to in the real world. In other words, it sepecifies the relationship between two linguistics expression. The characteristics of reference is shown from the existence of pronoun (Halliday and Hasan in Baker, 1992: 181). For example:

Bilingual Children's storybook entitled: Kancil Jadi Raja

The first text: One shiny morning in the jungle where kancil (a mouse deer) and his friends lived, the sun's rays had just radiated.

The article the in the sentence refer to jungle and sun light. While where refers to the jungle as a place for Kancil's and his friends lived. This is an example of reference.

The second text: Kancil's friend like an elephant and a water buffalo seem to

banter back and forth. They were occupied with dancing and singing.

The pronoun they in the sentence above refers to elephant and water buffalo. This is an example of reference.

\section{Subtitution}

It replaced an item or items by another item. The items that commonly used in subtitution are do, one, and the same (Halliday and Hasan in Baker, 1992: 186).

The first text: So did the monkey.

The word did subtitute the sentence the monkey also wanted to be the king of the jungle. This is an example of subtitution.

The second text: All of the jungle inhabitants were dispersed all over to find the

medicine, the water of the green magic jewel. Some went to the mountain, to the

valley, and also in the river like what the elephant and water buffalo did.

The word did in the sentence subtitute the sentence All of the jungle inhabitants were dispersed all over to find the medicine the river is the place where elephant and water buffalo went to in the jungle. This is an example of subtitution.

\section{Elipsis}

It omitted an item, but still can be comprehended (Halliday and Hasan in Baker, 1992:187). For example:

The first text: They sought the medicine in the bush or the bank of the river.

The word sought in the sentence is omitted, but it is not changing the information. This is an example of elipsis.

The second text: The monkey picks up some coconut fruits fast and then he gave to Kancil.

The phrase coconut fruits in the sentence is omitted in the sentence 'and then he gave to Kancil', but it is not changing the information. This is an example of elipsis.

\section{Conjunction}

It relates words, sentence, and paragraphs to each other. The characteristics of the sentence can be seen from the use of the conjunction, such as and, or, also, but, yet, then, next, and etc (Halliday and Hasan in Baker, 1992:190). For example:

The first text: Kancil's friend like an elephant and a water buffalo seem to banter back and forth. They were occupied with dancing and singing. 
The conjunction and connect the first and second sentence. This is an example of Conjunction.

The second text: Some went to the mountain, to the valley, and also in the river

like what the elephant and water buffalo did.

The conjunction and also, and connect the first and second sentence in order to provide a clear meaning. This is an example of Conjunction.

\section{Lexical Cohesion}

It refers to the role of vocabulary to organize it in a text. It divides into two parts: Reiteration and Collocation (Halliday and Hasan in Baker, 1992: 202-203). Reiteration means that it involves a repetition of lexical items. It could be a repetition, synonym, near synonym, superordinate or a general word. For example:

The text such as "The tiger can be recovered by the water of the green magic jewel. That's the news my friends...", said the parrot. The water could be found in a remote place. The water also had a lot of benefit and useful for creatures is considered as Repetition in Reiteration, because there is a repetition in the word the water. While, Collocation involves a pair of lexical items that are connected each other in the language in a certain way (Halliday and Hasan in Baker, 1992: 202-203). For example:

Associations based on a history of co-occurence:

Animals: tiger, parrot, mouse derr, elephant, water buffalo and monkey.

Jungle: the king of the jungle, cave, river, valley and mountain.

Opposite of meaning: Back/forth.

From the cohesion aspect, it can be concluded that the text is considered cohesive, because it fulfills the requirement of the cohesive devices. In the text there are linking words and repetition of words which give a clear information to the readers, especially for children in Indonesian as the first language and English as foreign language.

\section{CONCLUSION}

From the analysis and the findings of the study with regards to the research questions, the conclusion were as follows:

The first research question had to do with the translation strategies applied by the translator in translating bilingual chidren storybooks. It can be identified that there were eleven (11) types of translation strategies applied by the translator which was in line with skopos theory or more likely to emphasized on the Target Text (TT), among others: Transference strategy applied six (6) times, Cultural Equivalent strategy applied sthirty two (32) times, Transposition strategy applied nine (9) times, Modulation strategy applied seven (7) times, Reduction strategy applied eight (8) times, Expansion strategy applied six (6) times, Couplets strategy applied twelve (12) times, Triplets strategy applied eight (8) times, Quadruplets strategy applied four (4) times , Notes strategy applied two (2) times and Synonymy strategy applied two (2) times. The strategies applied is in total of one hundred and fourteen (114) translation strategies. Thus, it can be concluded that the strategies was suitable with the Skopos theory, where it focused on the Target Text (TT) and it can also be concluded that this translation product was suitable with the skopos theory. It can be identified from the rules of skopos: 
1. A translatum (or TT) is determined by its skopos.

2. A TT is an offer of information (informationsangebot) in a target culture and TL concerning an offer of information in a source culture and SL.

3. A TT does not initiate an offer of information in a clearly reversible way.

4. A TT must be internally coherent.

5. A TT must be coherent with ST.

6. The five rules above stand in hierarchical order, with the skopos rule predominating.

In rule no. 1 the skopos of the translation is to help the young learner in Indonesia to learn English using bilingual children storybook and to be well accepted in the market. In rule no.2, since the books were meant to be read by Indonesian Children, then the culture was not changing. In rule no.3, the original text or literary text, it was an advanced text. Therefore it was the translator's obligation to formulate it in a much more comprehensible text to be read by the target receiver and for that reason; the translation could not be retranslated in a reversible way. In rule no. 4 it can be concluded that the TT in children bilingual storybooks was coherent. In rule no 5. The TT must be coherent with ST. For these bilingual children storybooks, it can also be concluded that the TT was coherent with ST. Moreover, when the TT fulfill the Skopos, then it was functionally (to help children learning English) adequate (appropriate).

Related to the criteria of a good translated children storybook proposed by Tina Puurtinen (1994) cited in Shadrah (2010: 42), it can be concluded that this bilingual children storybooks were good translated children storybooks. This can be identified from the acceptability aspect, among others, the Dynamic style (i.e. Simple syntactic constructions with finite verbs are preferable, for example: readability (easy to read and understandable): these books were readable, and speakability (easy to read aloud fluently): the bilingual children storybooks were also speakable. 


\section{REFERENCES}

Anderson and Anderson. (1997). Text Types in English. Mcmillan Education. Australia Baker, M. (1992). In Other Words: A Course Book on Translation. Routledge. London. Baker, M and Malmkjaer, K. (2001). Routledge Encyclopedia of Translation Studies. Routledge. London.

Bell. T. R. (1991). Translation and Translating: Theory and Practice. Longman Group. NewYork.

Cameron, L. (2001). Teaching Languages to Young Learners. Cambridge University Press. UK

Chesterman, A. (2011). Translation Theory Course. http://www.helsinki.fi/ chesterm/ TransTheory.html\#Strategies.

Dollerup, C and Lindegaard, A. (1994). Teaching Translation and Interpreting 2: Insights, Aims, Visions. Papers from the Second Language International Conference (Denmark). Jonh Benjamins. Amsterdam

Gallagher, J.D. (1996). Training in the Application of Translation Strategies for Undergraduate scientific Translation. http://www.erudit.org/revue/meta/ 2001/v46/n4/ 002490ar.pdf

Hana, J. (2011). Terapi Kecerdasan Anak Dengan Dongeng. Berlian Media. Yogyakarta.

Hartono, Y. (2008). Kancil Jadi Raja. DINARMEDIA. Jakarta.

Hatim, B. (2001). Teaching and Researching Translation. Longman. England

Jaleniauskiene, E and Čyčelyté, V. (2009). The Strategies for Translating Proper Names in Children's Literature. Studies About Languages no.15. http://www.kalbos.lt/zurnalai/15_numeris/06.pdf

Jindan, S. (2011). The Functionalist Skopos Theory and Movie Title Translation. http://spdc.shnu.edu.cn/1000011102/......./009.doc. Date: October 11. 2011

Larson, L. M. (1984). Meaning Based Translation: A Guide to Cross-language Equivalence. University Press of America. Lanham.

Leuven Zwart. (1989). K. M. Van. (1989). Translation and Original: Similarities and Dissimilarities I. John Benjamins Publishing Company

Molina, L and Albir, H. A. (2002). Translation Techniques Revisited: A Dynamic and Functionalist Approach. Meta: Translator's Journal. Vol. 47 No. 4. http://www.erudit.org/revue/meta/2002/v47/n4/008033ar.pdf

Munday, J. (2001). Introducing Translation Studies. Routledge. New York.

Nababan, R.M. (2008). Kompetensi Penerjemahan dan Dampaknya Pada Kualitas Terjemahan. Pidato Pengukuhan Guru Besar Penerjemahan Pada Fakultas Sastra dan Seni Rupa Universitas Sebelas Maret.

Newmark, P. (1988). A textbook of Translation. Prentice Hall International LTD. UK

Nida and Taber. (1982). The Theory and Practice of Translation. Brill Leiden - Boston

Nord. C. (1993). Functional Approach to Translation. http://www.pfri.uniri.hr /2bopri/documents/obnord-stanalysis-foi_001.pdf

Nord. C. (1997). Translating as Purposeful Activity: Functionalist Approach Explained. ST. JEROME Publishing. UK

Pujianty, U. (2006). Strategies of Translating Personal Pronouns in the Disney's Fairy Tale Entitled Beauty and the Beast into Indonesian Version. An Undergraduate Thesis of English Department. Universitas Sebelas Maret. Surakarta. 
Pöchhacker, F. (1995). Simultaneous Interpreting : A Functionalist Perspective. Journal of Linguistics no. 14. http://scholar.googleusercontent.com /scholar?q= cache:tpdre_hpurkj: scholar.google.com/+process+of+translation+according+to +skopos+theory\&hl=id\&as_sdt=o\&as_'

Pym, A. (2010). Exploring Translation Theories. Routledge. NewYork

Reiss, K. (2000). Translation Criticism: The Potentials \& Limitation. St. Jerome Publishing Manchester. UK

Robinson, D. (1997). Becoming a Translator. Routledge. London.

Sas, I. (2010). The Treacle Triplets: A Functional Approach to The Translation of Children's Literature. http:/www.scholar.sun.ac.za/bitstream/handle/ 10019.1/ 5344/sas_treacle_2010.pdf?sequence=2.

Savory, T. (1968). The Art of Translation. Jonathan Cape Ltd. London.

Schaffner, C and Adab, B. (2000). Developing Translation Competence. John Benjamins B.V. USA.

Semingson, Pole and Tommerdahl. (2015). Using Bilingual Books To Enhance Literacy Around the World. European Scientific Journal vol 3. http://eujournal.org

Shadrah, N. I. (2010). A Translation Analysis of Colloquial Expressions in the Children Storybook Entitled The Secret Life of Ms. Wiz. An Undergraduate Thesis of English Department. Universitas Sebelas Maret. Surakarta.

Suryana, Y. (2007). Translating Indonesian into English. A Postgraduate Thesis of English Department. Universitas Pendidikan Indonesia. Unpublished.

Translation Procedures and Strategy. (2011). http://www.pfri.uniri.hr/ bopri/documents /TRANSLATIONSTRATEGIES_002.pdf

Venuti, L. (2000). The Translation Studies Reader. Routledge. NewYork

Wright, A. (1995). Storytelling with Children. Oxford University Press. Oxford. 